ISSN 1678-3921

Journal homepage: www.embrapa.br/pab

For manuscript submission and journal contents, access: www.scielo.br/pab

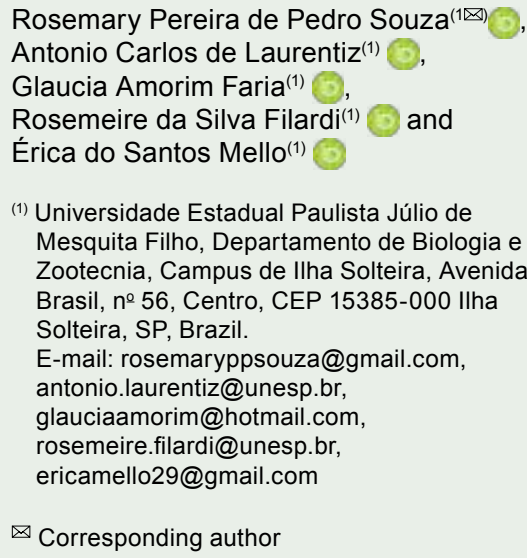

\section{Use of soybean gum as an emulsifier in diets for commercial laying hens}

\begin{abstract}
The objective of this work was to evaluate the influence of the inclusion of soybean (Glycine max) gum in the diet of laying hens on egg production, egg external and internal quality, and economic viability, as well as of temperature and storage time on the oxidative stability of eggs. One hundred and eighty 40 -week-old Lohmann-LSL layers were fed $0,1,2,3$, 4 , and $5 \%$ soybean gum in the diet. In the economic analysis, the average productive performance of the layers and the cost of feed were considered. In order to evaluate oxidative stability, eggs were stored at room temperature $\left(\sim 30^{\circ} \mathrm{C}\right)$ or refrigerated $\left(5^{\circ} \mathrm{C}\right)$ for 0,7 , and 21 days. The inclusion of soybean gum in the diet increased feed intake and also egg production, average weight, and mass. Soybean gum improved external and internal egg quality parameters, but reduced the Haugh unit. Oxidative stability was higher in eggs from hens fed $4 \%$ gum, at $5^{\circ} \mathrm{C}$, for 21 days; however, the largest economic return was with $1 \%$ gum. The inclusion of soybean gum promotes improvements in the production, external and internal quality, and oxidative stability of eggs from commercial laying hens.
\end{abstract}

Index terms: egg quality, lecithin, oxidative stability, performance, phosphatidylcholine.

\section{Uso de goma de soja como emulsificante em dietas para poedeiras comerciais}

Resumo - O objetivo deste trabalho foi avaliar a influência da inclusão de goma de soja (Glycine max) na dieta de poedeiras comerciais sobre a produção de ovos, a qualidade externa e interna dos ovos, e a viabilidade econômica, bem como da temperatura e do tempo de armazenamento sobre a estabilidade oxidativa dos ovos. Cento e oitenta poedeiras Lohmann-LSL com 40 semanas de idade foram alimentadas com $0,1,2,3,4$ e $5 \%$ de goma de soja na dieta. Na análise econômica, foram considerados o desempenho produtivo médio das poedeiras e o custo da ração. Para a avaliação da estabilidade oxidativa, os ovos foram armazenados à temperatura ambiente $\left(\sim 30^{\circ} \mathrm{C}\right)$ ou sob refrigeração $\left(5^{\circ} \mathrm{C}\right)$ por 0,7 e 21 dias. A inclusão de goma de soja na dieta aumentou o consumo de ração e também a produção, o peso médio e a massa dos ovos. A goma de soja melhorou os parâmetros de qualidade externa e interna dos ovos, mas reduziu a unidade de Haugh. A estabilidade oxidativa foi maior nos ovos de galinhas alimentadas com $4 \%$ de goma, a $5^{\circ} \mathrm{C}$, por 21 dias; entretanto, o maior retorno econômico foi com $1 \%$ de goma. A inclusão de goma de soja promove melhorias na produção, na qualidade externa e interna, e na estabilidade oxidativa dos ovos de poedeiras comerciais.

Termos para indexação: qualidade de ovos, lecitina, estabilidade oxidativa, desempenho, fosfatidilcolina. 


\section{Introduction}

Soybean [Glycine max (L.) Merr.] is one of the most important agricultural commodities in the national and world scene. Brazil is the second largest producer worldwide, with an estimate for the 2018/2019 harvest of 121.9 million tons (Acompanhamento..., 2019). The oil extracted from soybean through processing can be used for human and animal feed or for biofuel production, and its by-products are intended primarily for animal feed (Borsatti et al., 2018).

In the first stage of soybean processing, crude oil is extracted, and the obtained by-product is soybean meal, an important protein ingredient for poultry and swine feed. In the second stage, crude oil is subjected to hydration and centrifugation, in order to obtain the degummed soybean oil, and gums are the resulting by-product (Araújo, 2009). According to Mandalawi et al. (2015), soybean gum is the largest source of commercially available raw lecithin, which has antioxidant properties that protect polyunsaturated fatty acids, avoiding their oxidation and the production of free radicals (Aabdallah \& Eid, 2004).

The gums obtained after degumming contain $50 \%$ humidity and can be dried under vacuum (approximately $100 \mathrm{~mm} \mathrm{Hg}$ pressure) at 70 to $80^{\circ} \mathrm{C}$, being recognized as crude lecithin (Mandarino et al., 2015). This by-product consists of the combination of polar lipids (mostly phospholipids and glycolipids) and oil at an approximate ratio of 60:40, besides having a high content of unsaturated fatty acids (Nieuwenhuyzen \& Tomás, 2008), representing a good source of energy, linolenic acid, vitamin $\mathrm{E}$, choline, and emulsifying properties (Nguyen et al., 2014). In poultry feed, its energy value and emulsifying characteristics have been explored (Attia et al., 2009; Borsatti et al., 2018); however, there is not enough information available to recommend its use in broiler chicken feed (Viñado et al., 2019). In the case of laying hens, the information is even more restricted, both regarding the incorporation of gum (Leeson et al., 1977; Hulan \& Proudfoot, 1981) or raw lecithin in the feed (Mandalawi, 2015), mainly related to the quality of stored eggs. This is important since, as all products of animal origin, eggs are also perishable and begin to lose their internal quality after posture due to their high content of unsaturated fatty acids (Moura et al., 2008).

In a study carried out by Hulan \& Proudfoot (1981), hens fed diets containing soybean gum consumed more feed but maintained a production rate similar to that of the control hens; however, the addition of this by-product had no effect on the specific gravity and interior quality of eggs. Leeson et al. (1977) reported that the inclusion of the gum had no effect on feed intake or egg production.

The objective of this work was evaluate the influence of the inclusion of soybean gum in the diet of laying hens on egg production, egg external and internal quality, and economic viability, as well as of temperature and storage time on the oxidative stability of eggs.

\section{Materials and Methods}

The experiment was carried out at the poultry sector of Faculdade de Engenharia of Universidade Estadual Paulista Julio de Mesquita Filho (Unesp), located in the state of São Paulo, Brazil. A total of 180 40-weekold laying hens from the Lohmann-LSL line were used, which were previously selected according to their mean weight $(1.536 \pm 0.076 \mathrm{~kg})$ and posture rate $(80 \%)$, in order to standardize each experimental unit. The hens were housed in a conventional stall, equipped with galvanized wire cages, with four $25 \times 40 \times 40-\mathrm{cm}$ compartments, distributed laterally on two floors. A galvanized trough-style feeder - one per cage, fixed at the front - and cup-type drinker were used.

The experimental period was of 16 weeks, i.e., four cycles of 28 days, and the hens were distributed in a completely randomized design, with six treatments, five replicates, and six animals per experimental plot. Treatments consisted of six inclusion levels of soybean gum: 0 (control), 1, 2, 3, 4, and 5\%. The experimental diets were formulated using corn and soybean meal (Table 1) according to the ingredient composition (Rostagno, 2011) and nutritional recommendations described in the management guide for the line (Lohmann do Brasil, 2011).

Feed and water were supplied ad libitum throughout the experimental period, with feed intake being quantified at the end of each cycle. The adopted lighting was 16 hours light per day, following the guide for the line (Lohmann do Brasil, 2011).

Feed intake was calculated by the difference between the feed quantities supplied for each plot and the orts at the end of each cycle. Egg production and mortality were registered daily on forms. In the case of 
dead hens during the experimental period, the average consumption was corrected to obtain the true mean consumption for the experimental unit.

At the end of each cycle, the following productive parameters were determined: feed intake (grams per hen per day), egg production (\%), egg mass ( $\mathrm{g}$ ), and feed conversion ratio $\left(\mathrm{kg} \mathrm{kg}^{-1}\right)$.

During the experimental period, data on egg production per plot were collected, by estimating the number of days of laying in relation to the quantity of produced eggs.

In the last two days of each cycle, egg external and internal quality parameters were evaluated, considering, respectively: specific gravity, shell percentage, and shell thickness; and Haugh unit, yolk color, and $\mathrm{pH}$ values of yolk and albumen.

The average weight of the eggs was obtained based on the data of total weight and number of eggs from each experimental unit. After weighed, the eggs were immersed in saline solutions at different densities, ranging from 1.055 to $1.100 \mathrm{~g} \mathrm{~cm}^{-3}$. Egg density was considered to be the one at which the egg floated.

Three eggs per plot were collected, weighed separately, and then broken on a flat and smooth glass surface. Albumen height ( $\mathrm{mm}$ ) was measured with the 547-561S tube thickness gage (Mitutoyo, Kawasaki, Japan). After measuring albumen height and egg unit weight (g), the values of the Haugh unit were calculated

Table 1. Percentage of the used ingredients and calculated and determined compositions of the experimental diets containing different levels of inclusion of soybean (Glycine max) gum for commercial laying hens.

\begin{tabular}{|c|c|c|c|c|c|c|}
\hline \multirow[t]{2}{*}{ Ingredients } & \multicolumn{6}{|c|}{ Levels of inclusion of soybean gum (\%) } \\
\hline & 0 & 1 & 2 & 3 & 4 & 5 \\
\hline Corn & 55.35 & 53.80 & 52.47 & 50.69 & 49.13 & 47.60 \\
\hline Soybean meal & 30.21 & 30.47 & 30.69 & 30.93 & 31.20 & 31.40 \\
\hline Calcitic limestone & 9.53 & 9.53 & 9.53 & 9.53 & 9.53 & 9.53 \\
\hline Soybean oil & 2.50 & 2.81 & 3.13 & 3.44 & 3.75 & 4.07 \\
\hline Dicalcium phosphate & 1.720 & 1.726 & 1.726 & 1.733 & 1.740 & 1.740 \\
\hline Common salt & 0.359 & 0.360 & 0.361 & 0.362 & 0.362 & 0.363 \\
\hline DL-methionine & 0.175 & 0.178 & 0.180 & 0.182 & 0.184 & 0.187 \\
\hline Fatec polimix $\operatorname{Pr} 101^{(1)}$ & 0.100 & 0.100 & 0.100 & 0.100 & 0.100 & 0.100 \\
\hline L-lysine HCL & 0.056 & 0.052 & 0.048 & 0.044 & 0.041 & 0.037 \\
\hline Soybean gum & 0 & 1.000 & 2.000 & 3.000 & 4.000 & 5.000 \\
\hline Total kg & 100 & 100 & 100 & 100 & 100 & 100 \\
\hline \multirow[t]{2}{*}{ Cost per kg $(\mathrm{R} \$)$} & 0.982 & 0.985 & 0.989 & 0.993 & 0.999 & 1.003 \\
\hline & \multicolumn{6}{|c|}{ Calculated composition } \\
\hline Metabolizable energy $\left(\mathrm{kcal} \mathrm{kg}^{-1}\right)$ & \multicolumn{6}{|c|}{2.800} \\
\hline Calcium (\%) & 4.20 & 4.20 & 4.20 & 4.20 & 4.20 & 4.20 \\
\hline Available phosphorus (\%) & 0.42 & 0.42 & 0.42 & 0.42 & 0.42 & 0.42 \\
\hline Sodium $(\%)$ & 0.18 & 0.18 & 0.18 & 0.18 & 0.18 & 0.18 \\
\hline Digestible lysine (\%) & 0.92 & 0.92 & 0.92 & 0.92 & 0.92 & 0.92 \\
\hline Digestible methionine (\%) & 0.44 & 0.44 & 0.44 & 0.44 & 0.44 & 0.44 \\
\hline \multirow[t]{2}{*}{ Digestible methionine + cystine $(\%)$} & 0.69 & 0.69 & 0.69 & 0.69 & 0.69 & 0.69 \\
\hline & \multicolumn{6}{|c|}{ Determined composition $^{(2)}$} \\
\hline Ethereal extract & 7.16 & 7.77 & 8.20 & 8.73 & 9.33 & 10.36 \\
\hline Crude protein & 18.82 & 18.34 & 18.56 & 18.16 & 18.21 & 18.67 \\
\hline
\end{tabular}

(1) Manufacturer's recommendation for composition per kilogram of feed: 8,000 IU vitamin A, 2,100 IU vitamin D3, 7.0 mg vitamin E, $2.0 \mathrm{mg}$ vitamin $\mathrm{K} 3,1.0 \mathrm{mg}$ vitamin $\mathrm{B} 1,3.0 \mathrm{mg}$ vitamin B2, $0.7 \mathrm{mg}$ vitamin B6, $6.0 \mathrm{mcg}$ vitamin B12, $0.10 \mathrm{mg}$ folic acid, $0.01 \mathrm{mg}$ biotin, $20 \mathrm{mg}$ niacin, $10 \mathrm{mg}$ calcium pantothenate, $6.0 \mathrm{mg}$ copper, $0.10 \mathrm{mg}$ cobalt, $1.0 \mathrm{mg}$ iodine, $50 \mathrm{mg}$ iron, $55 \mathrm{mg}$ manganese, $50 \mathrm{mg}$ zinc, $0.20 \mathrm{mg}$ selenium, and $2.0 \mathrm{mg}$ antioxidant. (2) Composition determined in the Laboratory of Bromatology of the Department of Biology and Animal Science of Faculdade de Engenharia of Universidade Estadual Paulista Júlio de Mesquita Filho, located in the state of São Paulo, Brazil. 
by the equation described by Silversides \& Budgell (2004): $\mathrm{UH}=100 \log \left(\mathrm{H}+7.75-1.7 \mathrm{~W}^{0.37}\right)$, where $\mathrm{H}$ is albumen height $(\mathrm{mm})$ and $\mathrm{W}$ is egg weight $(\mathrm{g})$.

The yolk color analysis was performed using the DSM Yolk Color Fan (DSM, Heerlen, Netherlands). Subsequently, eggshells were washed in running water, dried at room temperature for 48 hours, weighed in a semi-analytical scale to obtain shell weight and, then, shell percentage. The 547-500S digital thickness gauge (Mitutoyo, Kawasaki, Japan) was used to determine shell thickness (mm).

For the $\mathrm{pH}$ analysis, three eggs from each plot were broken, the albumen and yolk were separated, placed in properly-identified disposable cups, and later homogenized with the aid of the B474 digital $\mathrm{pH}$ meter (Micronal, S.A., São Paulo, SP, Brazil) to obtain their $\mathrm{pH}$ value.

To determine the dry matter, crude protein, ethereal extract, crude fiber, and mineral matter of the experimental diets, ration samples were collected and sent to the Bromatology Laboratory of the Biology and Animal Science Department of Faculdade de Engenharia of Unesp. The bromatological analyzes were performed according to Silva \& Queiroz (2006).

In the last cycle, 180 eggs (six from each experimental unit) were selected, based on the absence of cracks, spots, or bark in their shells, for lipid oxidation measurements using the thiobarbituric acid reactive substances (TBARS) method, adapted from Vyncke (1970) and Ramanathan \& Das (1992). Subsequently, these eggs were randomly distributed in a $6 \times 2 \times 3$ factorial arrangement, with six inclusion levels of soybean gum $(0,1,2,3,4$, and $5 \%)$, two storage environments (average ambient temperature of $30^{\circ} \mathrm{C}$ and refrigeration at $5^{\circ} \mathrm{C}$ ), and three storage periods (fresh, 7 and 21 days).

For the economic analysis, the average performance of the hens during the whole experimental period was considered, and, for the cost of production, only the cost of feed. The cost of feed to produce $1 \mathrm{~kg}$ eggs was determined by considering the amount of feed consumed by the hens to produce $1 \mathrm{~kg}$ eggs and the price per kilogram of feed. The costs of the ingredients used in the formulation of the rations were based on the quotation made on 12/15/2016 for July, in the region of Bastos, in the state of São Paulo.

The economic viability analysis was performed by adapting the economic feed efficiency (EFE) index, as suggested by Houndonougbo et al. (2009). This index includes the income from egg production and the costs of feed. Therefore, the higher the EFE index, the better the cost-benefit ratio of production. For laying hens, this index was calculated by the formula: $\mathrm{EFE}=($ kilogram of produced egg $\times$ price per kilogram of egg) / (feed intake $\times$ price per kilogram of feed).

Data were subjected to the analysis of variance through the SAS software, version 9.4 (SAS Institute Inc., Cary, NC, USA). When a significant difference between treatments was observed for animal performance, egg quality, and economic viability, Dunnett's test was used to compare the control (without soybean gum) with the other treatments, and the regression analysis was performed between treatments with gum inclusion. In the case of lipid oxidation, the analysis of variance followed the $6 \times 2 \times 3$ factorial arrangement.

\section{Results and Discussion}

Feed intake, egg production, average egg weight, and egg mass differed between treatments and the control. The highest feed intake was observed in the treatment with the inclusion of 5\% soybean gum (Table 2), whereas the highest egg production was verified in the treatments with 3 and 5\%. The average egg weight increased with the inclusion of 3\% soybean gum; however, the highest value was obtained with 5\% of this by-product. A similar trend was observed for egg mass, which increased with the inclusion of $3 \%$ gum, but reached its highest value with the inclusion of $5 \%$, compared with the control.

In the regression analysis of the inclusion levels of soybean gum, feed intake, egg production, average egg weight, and egg mass showed an increased linear effect, whereas feed conversion had a decreased linear effect (Table 2).

Although the information available about the effects of soybean gum or other emulsifiers on the diet of laying hens is very limited, these ingredients are known to be extra-caloric (Bertechini, 2006), affecting the obtained results. According to the author, this characteristic results in improved palatability, reduced nutrient loss, supply of essential fatty acids and fat-soluble vitamins, low caloric increment, and reduced feed passage rate through lipid inclusion. 
The variation of oil inclusion in the control and in the diet with $5 \%$ soybean gum was only $1.5 \%$, showing that the increase in feed intake was favored by gum inclusion and not by the amount of oil present. Therefore, the formulation of isocaloric experimental diets must take this factor into account, so that the experimental results are not impaired by this effect (Junqueira et al., 2005).

In a study carried out by Hulan \& Proudfoot (1981) with hens fed diets containing soybean gum, this byproduct did not significantly affect egg production, but significantly increased the amount of feed required to produce a dozen eggs. However, when egg size was taken into account (kilogram of feed per kilogram of eggs), this difference disappeared, i.e., hens fed diets containing soybean gum consumed more feed but maintained a production rate similar to that of the control hens. These results are contrary to those of Leeson et al. (1977), who reported that the addition of the gum had no effect on feed intake or egg production.

Another factor that may have contributed to the increase in feed intake is the presence of choline, a part of the lecithin structure that participates in the composition of soybean gum (Leeson \& Summers, 2001). Vasconcelos et al. (2013) also found that choline supplementation in the diets of laying hens increased feed intake.
According to Attia et al. (2009), the use of 3 and 6\% lecithin in the diets of laying hens increases egg weight and mass. The presence of lecithin in the composition of soybean gum probably favored the increase of egg weight and mass in the treatments that received the highest inclusion levels.

The control and the other treatments differed regarding Haugh unit, specific gravity, shell thickness, shell percentage, and yolk color (Tables 3 and 4). For the Haugh unit, lower results were observed in the treatments with the inclusion of 4 and 5\% soybean gum. The inclusion of $3 \%$ gum caused a reduction both in specific gravity, i.e., reduced shell quality, and in the percentage of shell. Regarding shell thickness, it was thinner in the treatments with the inclusion of 3 and 5\% soybean gum, compared with the control. For the parameters expressing external egg quality, the regression analysis of soybean gum inclusion levels in the diet showed a decreasing linear effect, indicating that the increase in the inclusion of this by-product decreases the external quality of eggs (Table 3); this effect was opposite to that observed for egg weight, which increased with the increase in gum inclusion (Table 2). Those results corroborate the ones found by Garcia et al. (2015), who observed that the increase in egg size is directly related to the worsening of shell quality.

Table 2. Performance parameters of hens fed diets containing different levels of inclusion of soybean (Glycine max) gum.

\begin{tabular}{|c|c|c|c|c|c|}
\hline \multirow[t]{2}{*}{ Treatment } & \multicolumn{5}{|c|}{ Parameter } \\
\hline & $\begin{array}{c}\text { Feed intake } \\
\text { (g per hen per day) }\end{array}$ & $\begin{array}{c}\text { Egg production } \\
(\%)\end{array}$ & $\begin{array}{l}\text { Egg weight } \\
(\mathrm{g})\end{array}$ & $\begin{array}{l}\text { Egg mass } \\
(\mathrm{g})\end{array}$ & $\begin{array}{c}\text { Feed conversion } \\
\left(\mathrm{kg} \mathrm{kg}^{-1}\right)\end{array}$ \\
\hline Control & 97.07 & 90.24 & 60.58 & 54.720 & 1.846 \\
\hline $1 \%$ & $101.89^{\text {ns }}$ & $91.80^{\text {ns }}$ & $61.07^{\mathrm{ns}}$ & $56.05^{\text {ns }}$ & $1.81^{\mathrm{ns}}$ \\
\hline $2 \%$ & $102.06^{\mathrm{ns}}$ & $91.04^{\mathrm{ns}}$ & $62.11^{\mathrm{ns}}$ & $56.26^{\mathrm{ns}}$ & $1.77^{\mathrm{ns}}$ \\
\hline $3 \%$ & $103.20^{\mathrm{ns}}$ & $93.93 *$ & $62.58^{*}$ & $58.81^{*}$ & $1.71^{\mathrm{ns}}$ \\
\hline $4 \%$ & $103.22^{\mathrm{ns}}$ & $93.52^{\mathrm{ns}}$ & $63.15^{*}$ & $59.06^{*}$ & $1.75^{\text {ns }}$ \\
\hline $5 \%$ & $104.74 *$ & $94.59^{*}$ & $63.46^{*}$ & $60.83 *$ & $1.70^{\mathrm{ns}}$ \\
\hline \multirow[t]{2}{*}{$\operatorname{MSD}^{(1)}$} & 3.63 & 3.38 & 1.65 & 3.23 & 0.14 \\
\hline & \multicolumn{5}{|c|}{$\mathrm{p}$-value in the regression analysis } \\
\hline Linear & 0.039 & 0.0004 & 0.000 & 0.000 & 0.182 \\
\hline Quadratic & 0.965 & 0.969 & 0.425 & 0.988 & 0.420 \\
\hline Deviation & 0.513 & 0.179 & 0.943 & 0.400 & 0.864 \\
\hline Equation & $y=68.57 x+100.97$ & $y=80.5 x+90.56$ & $y=58.21 x+60.73$ & $y=123.47 x+54.50$ & $y=-2.45 x+1.82$ \\
\hline $\mathrm{R}^{2}$ & 0.90 & 0.73 & 0.96 & 0.93 & 0.75 \\
\hline
\end{tabular}

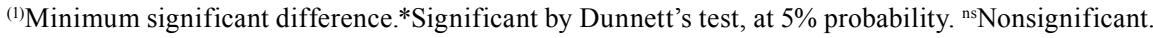


When using ingredients with high amounts of free fatty acids (FFAs), such as soybean oil, in the diets of laying hens, it is important to consider that these FFAs can react with some minerals, such as calcium, forming soaps. If these soaps are insoluble, they can make minerals unavailable to the hen, by negatively affecting their retention, consequently reducing eggshell quality (Bregendahl, 2006). In present study, specific gravity, shell percentage, and shell thickness decreased with increased soybean gum inclusion, even in the treatments that received the highest level of $5 \%$ (Table 3); this shows that the amount of lecithin present in the gum, at the used inclusion levels, was not sufficient to prevent soap formation.

For yolk color, the inclusion of $2 \%$ soybean gum improved pigmentation, and 3\% gum resulted in the most intense yolk color (Table 4). The vast majority of egg components are metabolized in the liver, and the accumulation of nutrients in the bloodstream causes them to be transported to the hen's ovary, where the deposition of liposoluble compounds, lipids, phospholipids, cholesterol, and carotenoids occurs, causing the yellow-orange color in the yolk (Lopes et

Table 3. External parameters of the egg quality of hens fed diets containing different levels of inclusion of soybean (Glycine max) gum.

\begin{tabular}{lcccc}
\hline Treatment & \multicolumn{4}{c}{ Parameter } \\
\cline { 2 - 5 } & $\begin{array}{c}\text { Haugh } \\
\text { unit }\end{array}$ & $\begin{array}{c}\text { Specific gravity } \\
\left(\mathrm{g} \mathrm{cm}^{-3}\right)\end{array}$ & $\begin{array}{c}\text { Shell thickness } \\
(\mathrm{mm})\end{array}$ & $\begin{array}{c}\text { Percentage of } \\
\text { shell }(\%)\end{array}$ \\
\hline Control & 97.844 & 1.092 & 0.374 & 10.409 \\
$1 \%$ & $98.148^{\text {ns }}$ & $1.092^{\text {ns }}$ & $0.373^{\text {ns }}$ & $10.450^{\text {ns }}$ \\
$2 \%$ & $96.990^{\text {ns }}$ & $1.091^{\text {ns }}$ & $0.366^{\text {ns }}$ & $10.238^{\text {ns }}$ \\
$3 \%$ & $96.477^{\text {ns }}$ & $1.090^{*}$ & $0.358^{*}$ & $9.964^{*}$ \\
$4 \%$ & $95.388^{*}$ & $1.090^{*}$ & $0.363^{\text {ns }}$ & $9.923^{*}$ \\
$5 \%$ & $95.570^{*}$ & $1.088^{*}$ & $0.361^{*}$ & $9.961^{*}$ \\
\hline MSD ${ }^{(1)}$ & 2.10 & 0.0017 & 0.01 & 0.30 \\
\hline \multirow{4}{*}{ Linear } & 0.000 & 0.000 & 0.018 & 0.000 \\
Quadratic & 0.129 & 0.846 & 0.083 & 0.027 \\
Deviation & 0.500 & 0.249 & 0.548 & 0.726 \\
Equation & $y=-0.67 \mathrm{x}$ & $\mathrm{y}=-0.09 \mathrm{x}+$ & $\mathrm{y}=16.42 \mathrm{x}^{2}-$ & $\mathrm{y}=-12.93$ \\
$\mathrm{R}^{2}$ & +98.54 & 1.09 & $1.25 \mathrm{x}+0.38$ & +10.49 \\
\hline
\end{tabular}

(1)Minimum significant difference. *Significant by Dunnett's test, at $5 \%$ probability. ${ }^{\text {nNNonsignificant. }}$ al., 2011). A study conducted by Alleoni \& Antunes (2001) showed that the eggs of hens supplemented with $6 \%$ lecithin had a more intense yolk color. The presence of lecithin in the composition of soybean gum probably favored the absorption of lipids and carotenoids, which intensified yolk color in the treatment that received 3\% soybean gum.

Yolk oxidative stability only differed in eggs obtained from the treatment with $4 \%$ soybean gum and that were stored under refrigeration for a period of 21 days (Table 5). This parameter did not differ for eggs stored under refrigeration during 7 days, although they showed less oxidation when soybean gum was used. This is an indicative that the antioxidant action of soybean gum, allied to refrigeration, contributed to a better oxidative stability of eggs.

Regarding the economic evaluation data, only the values obtained for the EFE index differed when treatments were compared with the control (Table 6), indicating that the inclusion of $1 \%$ soybean gum in the diet provided a better economic return. In the regression analysis, a linear effect was found for cost of kilograms of produced eggs and a quadratic one, for the EFE index.

Table 4. Internal egg quality parameters of hens fed diets containing increasing levels of inclusion of soybean (Glycine max) gum.

\begin{tabular}{|c|c|c|c|}
\hline \multirow[t]{2}{*}{ Treatment } & \multicolumn{3}{|c|}{ Parameter } \\
\hline & $\mathrm{pH}$ of albumen & $\mathrm{pH}$ of yolk & Yolk color \\
\hline Control & 8.469 & 5.919 & 4.800 \\
\hline $1 \%$ & $8.478^{\mathrm{ns}}$ & 5.943 & $4.925^{\mathrm{ns}}$ \\
\hline $2 \%$ & $8.550^{\mathrm{ns}}$ & 5.950 & $5.125^{*}$ \\
\hline $3 \%$ & $8.556^{\mathrm{ns}}$ & 5.929 & $5.183^{*}$ \\
\hline $4 \%$ & $8.579^{\mathrm{ns}}$ & 5.919 & $5.141^{*}$ \\
\hline $5 \%$ & $8.531^{\mathrm{ns}}$ & 5.913 & $5.050^{*}$ \\
\hline \multirow[t]{2}{*}{$\mathrm{MSD}^{(1)}$} & 0.11 & 0.08 & 0.24 \\
\hline & \multicolumn{3}{|c|}{$\mathrm{p}$-value in the regression analysis } \\
\hline Linear & 0.146 & 0.220 & 0.248 \\
\hline Quadratic & 0.038 & 0.874 & 0.014 \\
\hline Deviation & 0.774 & 0.878 & 0.927 \\
\hline Equation & $\begin{array}{l}y=-0.01 x^{2}+ \\
0.10 x+8.38\end{array}$ & $\begin{array}{c}y=-0.009 x+ \\
5.95\end{array}$ & $\begin{array}{c}y=-487.14 x^{2}+ \\
31.89 x+4.66\end{array}$ \\
\hline $\mathrm{R}^{2}$ & 0.93 & 0.85 & 0.98 \\
\hline
\end{tabular}

(1)Minimum significant difference. *Significant by Dunnett's test, at $5 \%$ probability. ${ }^{\text {nNNonsignificant. }}$ 
Table 5. Oxidative stability of the egg yolk by TBARS of hens fed diets containing increasing levels of inclusion of soybean (Glycine max) gum ${ }^{(1)}$.

\begin{tabular}{|c|c|c|c|c|c|}
\hline \multirow[t]{2}{*}{ Treatment } & \multicolumn{5}{|c|}{$\begin{array}{l}\text { Oxidative stability of egg yolk by TBARS } \\
\left(\mathrm{mg} \text { malonaldehyde } \mathrm{kg}^{-1}\right)\end{array}$} \\
\hline & Fresh & $\begin{array}{l}\text { Env. } \\
\text { (7 days) }\end{array}$ & $\begin{array}{c}\text { Ref. } \\
\text { (7 days) }\end{array}$ & $\begin{array}{c}\text { Env. } \\
\text { (21 days) }\end{array}$ & $\begin{array}{c}\text { Ref. } \\
\text { (21 days) }\end{array}$ \\
\hline Control & 0.408 & 0.335 & 0.334 & 0.375 & 0.356 \\
\hline $1 \%$ & $0.453^{\text {ns }}$ & $0.409^{\text {ns }}$ & $0.261^{\mathrm{ns}}$ & $0.396^{\mathrm{ns}}$ & $0.330^{\mathrm{ns}}$ \\
\hline $2 \%$ & $0.434^{\mathrm{ns}}$ & $0.312^{\mathrm{ns}}$ & $0.310^{\mathrm{ns}}$ & $0.354^{\mathrm{ns}}$ & $0.324^{\mathrm{ns}}$ \\
\hline $3 \%$ & $0.426^{\mathrm{ns}}$ & $0.353^{\mathrm{ns}}$ & $0.298^{\text {ns }}$ & $0.424^{\mathrm{ns}}$ & $0.334^{\mathrm{ns}}$ \\
\hline $4 \%$ & $0.286^{\mathrm{ns}}$ & $0.412^{\mathrm{ns}}$ & $0.329^{\text {ns }}$ & $0.398^{\mathrm{ns}}$ & $0.298^{*}$ \\
\hline $5 \%$ & $0.352^{\mathrm{ns}}$ & $0.403^{\text {ns }}$ & $0.265^{\text {ns }}$ & $0.332^{\mathrm{ns}}$ & $0.349^{\text {ns }}$ \\
\hline \multirow[t]{2}{*}{ MSD } & 0.15 & 0.10 & 0.12 & 0.14 & 0.05 \\
\hline & \multicolumn{5}{|c|}{$\mathrm{p}$-value in the regression analysis } \\
\hline Linear & $0.016^{(2)}$ & 0.283 & 0.769 & 0.522 & 0.778 \\
\hline Quadratic & 0.814 & 0.058 & 0.107 & 0.357 & 0.209 \\
\hline Deviation & 0.157 & 0.061 & 0.571 & 0.379 & 0.097 \\
\hline
\end{tabular}

(1)TBARS, thiobarbituric acid reactive substances; Env., environment; Ref., refrigerated; and MSD, minimum significant difference. ${ }^{(2)}$ Linear equation $\mathrm{y}=-0.035 \mathrm{x}+0.4952 ; \mathrm{R}^{2}=0.63$. *Significant by Dunnett's test, at $5 \%$ probability. ${ }^{\mathrm{n}}$ Nonsignificant.

Table 6. Parameters of the economic analysis for the levels of inclusion of soybean (Glycine max) gum in the diets for commercial laying hens ${ }^{(1)}$.

\begin{tabular}{lcc}
\hline Treatment & $\begin{array}{c}\text { Cost per kg of egg } \\
(\mathrm{R} \$)\end{array}$ & EFE \\
\hline Control & 1.668 & 0.995 \\
$1 \%$ & $1.620^{\mathrm{ns}}$ & $1.004^{*}$ \\
$2 \%$ & $1.722^{\mathrm{ns}}$ & $1.000^{\mathrm{ns}}$ \\
$3 \%$ & $1.678^{\mathrm{ns}}$ & $1.000^{\text {ns }}$ \\
$4 \%$ & $1.746^{\mathrm{ns}}$ & $0.998^{\mathrm{ns}}$ \\
$5 \%$ & $1.754^{\mathrm{ns}}$ & $1.000^{\text {ns }}$ \\
\hline MSD & 0.157 & 0.006 \\
\hline & $\mathrm{p}-$ value in the regression analysis \\
Linear & 0.022 & 0.068 \\
Quadratic & 0.591 & 0.165 \\
Deviation & 0.316 & 0.499 \\
Equation & $\mathrm{y}=3.14 \mathrm{x}+1.6054$ & $\mathrm{y}=7.1429 \mathrm{x}^{2}-0.5286 \mathrm{x}+1.0084$ \\
$\mathrm{R}^{2}$ & 0.83 & 0.90 \\
\hline
\end{tabular}

${ }^{(1)} \mathrm{EFE}$, economic feed efficiency; and MSD, minimum significant difference. *Significant by Dunnett's test, at $5 \%$ probability.

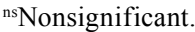

\section{Conclusions}

1. The inclusion of soybean (Glycine max) gum in the diets of commercial laying hens increases feed intake, egg production, average egg weight, and egg mass.

2. Regarding egg quality, the inclusion of soybean gum reduces Haugh unit values, but intensifies yolk color.

3. The higher soybean gum inclusion levels, associated with refrigerated storage, improve the oxidative stability of eggs.

4. The inclusion of $1 \%$ soybean gum provides the highest economic return.

\section{Acknowledgments}

To Coordenação de Aperfeiçoamento de Pessoal de Nível Superior (Capes), for scholarship; to Cargill Agrícola S.A., for sponsorship and technical support.

\section{References}

AABDALLAH, D.M.; EID, N.I. Possible neuroprotective effects of lecithin and $\alpha$-tocopherol alone or in combination against ischemia/reperfusion insult in rat brain. Journal of Biochemical and Molecular Toxicology, v.18, p.273-278, 2004. DOI: https://doi.org/10.1002/jbt.20037.

ACOMPANHAMENTO DA SAFRA BRASILEIRA [DE] GRÃOS: safra 2018/19: décimo segundo levantamento, v.6, n.11, set. 2019. Available at: <https://www.conab.gov.br/info-agro/ safras/graos/boletim-da-safra-de-graos $>$. Accessed on: Oct. 3 2019.

ALLEONI, A.C.C.; ANTUNES, A.J. Unidade Haugh como medida da qualidade de ovos de galinhas armazenados sob refrigeração. Scientia Agricola, v.58, p.681-685, 2001. DOI: https://doi.org/10.1590/S0103-90162001000400005.

ARAÚJO, J.M.A. Química de alimentos: teoria e prática. 4.ed. atual. e ampl. Viçosa: UFV, 2009. 596p.

ATTIA, Y.A.; HUSSEIN, A.S.; TAG EL-DIN, A.E.; QOTA, E.M.; ABED EL-GHANY, A.I.; EL-SUDANY, A.M. Improving productive and reproductive performance of dual-purpose crossbred hens in the tropics by lecithin supplementation. Tropical Animal Health and Production, v.41, p.461-475, 2009. DOI: https://doi.org/10.1007/s11250-008-9209-3.

BERTECHINI, A.G. Nutrição de monogástricos. Lavras: UFLA, 2006. 301p.

BORSATTI, L.; VIEIRA, S.L.; STEFANELLO, C.; KINDLEIN, L.; OVIEDO-RONDÓN, E.O.; ANGEL, C.R. Apparent metabolizable energy of by-products from the soybean oil industry for broilers: acidulated soapstock, glycerin, lecithin, and their mixture. Poultry Science, v.97, p.124-130, 2018. DOI: https://doi.org/10.3382/ps/pex269.

BREGENDAHL, K. Free fatty acids in diet for laying hens. Iowa: Department of Animal Science, 2006. 
GARCIA, E.R. de M.; ALVES, M.C.F.; CRUZ, F.K. da; CONTI, A.C.M.; BATISTA, N.R.; BARBOSA FILHO, J.A. Qualidade interna de ovos: efeito do armazenamento, linhagem e idade da poedeira. Revista Brasileira de Agropecuária Sustentável, v.5, p.101-109, 2015. DOI: https://doi.org/10.21206/rbas.v5i1.242.

HOUNDONOUGBO, F.M.; CHWALIBOG, A.; CHRYSOSTOME, C.A.A.M. Effect of commercial diets quality on bio-economic performances of broilers in Benin. Tropical Animal Health Production, v.41, p.693-703, 2009. DOI: https://doi.org/10.1007/s11250-008-9243-1.

HULAN, H.W.; PROUDFOOT, F.G. Performance of laying hens fed diets containing soybean gums, rapeseed gums and rapeseed meals with and without gums. Canadian Journal of Animal Science, v.61, p.1031-1040, 1981. DOI: https://doi.org/10.4141/ cjas81-127.

JUNQUEIRA, O.M.; ANDREOTTI, M. de O.; ARAÚJO, L.F.; DUARTE, K.F.; CANCHERINI, L.C.; RODRIGUES, E.A. Valor energético de algumas fontes lipídicas determinado com frangos de corte. Revista Brasileira de Zootecnia, v.34, p.2335-2339, 2005. Supl. DOI: https://doi.org/10.1590/S1516-35982005000700020.

LEESON, S.; SLINGER, S.J.; SUMMERS, J.D. Performance of laying hens fed diets containing gums derived from Tower rapeseed. Canadian Journal of Animal Science, v.57, p.479483, 1977. Available at: <https://www.nrcresearchpress.com/doi/ pdfplus/10.4141/cjas77-061>. Accessed on: Mar. 102019.

LEESON, S.; SUMEERS, J.D. Scott's nutrition of the chicken. $4^{\text {th }}$ ed. Guelph: University Books, 2001. 591p.

LOHMANN DO BRASIL. Guia de manejo: Lohmann LSL. São José do Rio Preto, 2011. 28p.

LOPES, I.R.V.; FREITAS, E.R.; LIMA, J.R.; VIANA NETO, J.L.; BEZERRA, R.M.; LIMA, R.C. Desempenho e qualidade dos ovos de poedeiras comerciais alimentadas com rações contendo farelo de coco tratado ou não com antioxidante. Revista Brasileira de Zootecnia, v.40, p.2431-2438, 2011. DOI: https://doi.org/10.1590/ S1516-35982011001100021.

MANDALAWI, H.A.; LÁZARO, R.; REDÓN, M.; HERRERA, J.; MENOYO, D.; MATEOS, G.G. Glycerin and lecithin inclusion in diets for brown egg-laying hens: effects on egg production and nutrient digestibility. Animal Feed Science and Technology, v.209, p.145-156, 2015. DOI: https://doi.org/10.1016/j. anifeedsci.2015.07.019.

MANDARINO, J.M.G.; HIRAKURI, M.H.; ROESSING, A.C. Tecnologia para produção do óleo de soja: descrição das etapas, equipamentos, produtos e subprodutos. 2.ed. Londrina: Embrapa Soja, 2015. 41p. (Embrapa Soja. Documentos, 171).
MOURA, A.M.A. de; OLIVEIRA, N.T.E. de; THIEBAUT, J.T.L.; MELO, T.V. Efeito da temperatura de estocagem e do tipo de embalagem sobre a qualidade interna de ovos de codornas japonesas (Coturnix japonica). Ciência Agrotécnica, v.32, p.578-583, 2008. DOI: https://doi.org/10.1590/S1413-70542008000200036.

NGUYEN, T.A.H.; NGO, HH.; GUO, W.S.; NGUYEN, T.V.; ZHANG, J.; LIANG, S.; CHEN, S.S.; NGUYEN, N.C. A comparative study on different metal loaded soybean milk byproduct 'okara' for biosorption of phosphorus from aqueous solution. Bioresource Technology, v.169, p.291-298, 2014. DOI: https://doi.org/10.1016/j.biortech.2014.06.075.

NIEUWENHUYZEN, W.; TOMÁS, M.C. Update on vegetable lecithin and phospholipid technologies. European Journal of Lipid Science and Technology, v.110, p.472-486, 2008. DOI: https://doi.org/10.1002/ejlt.200800041.

RAMANATHAN, L.; DAS, N.P. Studies on the control of lipid oxidation in ground fish by some polyphenolic natural products. Journal of Agricultural and Food Chemistry, v.40, p.17-21, 1992. DOI: https://doi.org/10.1021/jf00013a004.

ROSTAGNO, H.S. (Ed.). Tabelas brasileiras para aves e suínos: composição de alimentos e exigências nutricionais. 3.ed. Viçosa: UFV, 2011. 252p.

SILVA, D.J.; QUEIROZ, A.C. de. Análise de alimentos: métodos químicos e biológicos. 3.ed. 3. reimp. Viçosa: UFV, 2006. 235p.

SILVERSIDES, F.G.; BUDGELL, K. The relationships among measures of egg albumen height, $\mathrm{pH}$, and whipping volume. Poultry Science, v.83, p.1619-1623, 2004. DOI: https://oi.org/10.1093/ps/83.10.1619.

VASCONCELOS, R.J.C.; BAIÃO, N.C.; LARA, L.J.C.; ECCO, R.; MACHADO, A.L.C.; POMPEU, M.A.; ROCHA, J.S.R.; MIRANDA, D.J.A. Efeitos da suplementação de colina sobre o desempenho de poedeiras comerciais. Arquivo Brasileiro de Medicina Veterinária e Zootecnia, v.65, p.1116-1122, 2013. DOI: https://doi.org/10.1590/S0102-09352013000400026.

VIÑADO, A.; CASTILLEJOS, L.; RODRIGUEZ-SANCHEZ, R.; BARROETA, A.C. Crude soybean lecithin as alternative energy source for broiler chicken diets. Poultry Science, v.98, p.56015612, 2019. DOI: https://doi.org/10.3382/ps/pez318.

VYNCKE, W. Direct determination of the thiobarbituric acid value in trichloracetic acid extracts of fish as a measure of oxidative rancidity. Fette Seifen Anstrichmittel, v.72, p.10841087, 1970. DOI: https://doi.org/10.1002/lipi.19700721218. 